\title{
Energy and protein requirements of young Holstein calves in tropical condition
}

\author{
João Paulo Pacheco Rodrigues ${ }^{1}$. Jessika Carolina Moutinho Lima ${ }^{1}$. \\ Marcelo Messias Duarte Castro ${ }^{1}$ - Sebastião de Campos Valadares Filho ${ }^{1}$. \\ Mariana Magalhães Campos ${ }^{2} \cdot$ Mário Luiz Chizzotti ${ }^{1}$ - Marcos Inácio Marcondes ${ }^{1}$
}

Received: 7 October 2015 / Accepted: 15 June 2016 / Published online: 27 June 2016

(C) Springer Science+Business Media Dordrecht 2016

\begin{abstract}
Our objective was to estimate the energy and protein requirements of Holstein young calves up to 87 days old. Forty-two Holstein calves aged 4 days were used. From these, ten were randomly selected and slaughtered to compose the baseline slaughter (BS) group. The remaining calves were randomly assigned to eight treatments in a $4 \times 2$ factorial using a completely randomized design. The treatments were $2,4,6$, and $8 \mathrm{~kg} /$ day of milk ( $297 \mathrm{~g} / \mathrm{kg} \mathrm{CP} ; 319 \mathrm{~g} / \mathrm{kg}$ of fat) fed twice daily, and then harvested at 59 or 87 days of age. Calves were fed a starter (193 g/kg CP; $133 \mathrm{~g} / \mathrm{kg} \mathrm{NDF})$ ad libitum in all treatments. The calves slaughtered at 87 days of age had milk replaced by Coast-cross (Cynodoon sp.) hay (125 g/kg CP; $728 \mathrm{~g} / \mathrm{kg} \mathrm{NDF}$ ). The net requirement of energy for maintenance $\left(\mathrm{NE}_{\mathrm{m}}\right)$ was $0.36 \mathrm{MJ} / \mathrm{kg}$ EBWG, with efficiency of utilization of energy for maintenance $\left(k_{\mathrm{m}}\right)$ of $59.4 \%$. The equation obtained to estimate the net requirement of energy for gain $\left(\mathrm{NE}_{\mathrm{g}} ; \mathrm{MJ} / \mathrm{d}\right)$ was $4.40 \times \mathrm{EBW}^{0.099}$, with the efficiency of utilization of energy for gain $\left(k_{\mathrm{g}}\right)$ equal to $46.5 \%$. The observed requirements of net and metabolizable protein for maintenance $\left(\mathrm{NP}_{\mathrm{m}}\right.$ and $\left.\mathrm{MP}_{\mathrm{m}}\right)$ were 3.67 and $3.88 \mathrm{~g} / \mathrm{kg}$ $\mathrm{BW}^{0.75}$, respectively. The efficiency of use of metabolizable protein for maintenance $\left(k_{\mathrm{pm}}\right)$ was $94.6 \%$. The predicted requirements were higher than those observed in the literature, and this study demonstrated that the requirements of newborn calves are higher than the recommended.
\end{abstract}

Marcos Inácio Marcondes

marcosinaciomarcondes@gmail.com

1 Department of Animal Science, Universidade Federal de Viçosa, 36570-900 Viçosa, Minas Gerais, Brazil

2 Embrapa, Brazilian Agricultural Research Corporation, 36038-330 Juiz de Fora, Minas Gerais, Brazil
Keywords Comparative slaughter - Efficiency of utilization · Growth $\cdot$ Maintenance $\cdot$ Metabolizable energy $\cdot$ Metabolizable protein

\section{Introduction}

Systems for the prediction of nutritional requirements of young calves use sparse databases (NRC 2001; AFRC 1993), and the NRC (2001) emphasizes the lack of information on animals under $100 \mathrm{~kg}$ of body weight. Despite the recognized demand, in recent years there are few studies aiming to predict nutrient requirements of this animal category (Bartlett et al. 2006; Labussiere et al. 2008).

The energy requirements of young calves are mostly based on data estimated from respirometric techniques (Arieli et al. 1995; NRC 2001), with little information based on comparative slaughter (Gerrits et al. 1996). Bascom et al. (2007) showed indications that the NRC (2001) requirements of protein for maintenance are underestimated. The NRC (2001) values adopted to estimate protein requirements for maintenance of young animals are based on factorial methods of $\mathrm{N}$ losses (Blaxter and Mitchell 1948). The use of factorial methods to estimate protein requirements of calves has a limitation related to the demand for accurate estimates of starter intake to predict endogenous $\mathrm{N}$ losses in feces. The solid feed intake depends on the level of milk feeding and starter composition, having few data to predict accurate values of starter intake (Silva et al. 2014). Therefore, the estimation of requirements based on information such as body weight can avoid biased estimates.

Accurate predictions of nutrient requirements of young calves are needed in order to meet the requirements of these animals. Due to the relevance and demand for specific information for young animals, this study was conducted with the 
objective to estimate the nutrient requirements of energy and protein for the maintenance and growth of Holstein calves until 87 days of age in tropical condition.

\section{Materials and methods}

The ethics committee of the Universidade Federal de Viçosa approved the management and slaughter procedures (protocol no. 012/2012).

\section{Animals and feeding}

Forty-two non-castrated Holstein calves, with an average initial body weight of $35.6 \pm 5.9 \mathrm{~kg}$, at 3 days of age, were used. The animals were acquired from nine farms in Viçosa, Minas Gerais State, Brazil. All of the selected farms receive technical support from the dairy extension program of the institution. Colostrum feeding was performed at the properties, providing at least $10 \%$ of calf birth weight of colostrum daily until 3 days old. The entry of animals in the experiment occurred at their fourth day of life. All animals were treated on the third day of life against endo and ectoparasites (Dectomax ${ }^{\circledR}, 1 \mathrm{~mL}$, Pfizer Animal Health) and supplemented with vitamins A, D, and E (A-D-E, $5 \mathrm{~mL}$, Pfizer Animal Health). Three calves died during the course of the trial because of diarrhea (two cases; 14 and 19 days old) and bloat (one case; 24 days old). The average, minimum, and maximum temperatures were measured daily on a meteorological station near the experimental area, and were $21.8( \pm 2.4), 6.0$, and $33.6{ }^{\circ} \mathrm{C}$, respectively.

Ten calves were randomly selected to compose the baseline slaughter (BS) group. The other 29 were housed in individual stalls, arranged in a completely randomized $4 \times 2$ factorial design. The four treatments used were as follows: $2,4,6$, and $8 \mathrm{~kg}$ /day of whole milk (Table 1), supplied in two meals (0600 and 1600 hours) with buckets. In all treatments, starter (Table 1) was offered ad libitum. In each milk level, four calves were slaughtered at 59 days of age, and the other four were weaned on the 60th day, having their milk replaced by Coast-cross (Cynodon spp.) hay and the same initial starter (Table 1) ad libitum, and subsequently slaughtered at 87 days of life. Intake was measured daily for each calf. Weekly samples of all feeds were collected to calculate the nutrient intake.

\section{Digestibility trials and calculation of metabolizable energy and protein}

Total feces were collected for $48 \mathrm{~h}$ to evaluate the digestibility of the diets. To estimate the rumen microbial protein synthesis, urine was collected at the first $24 \mathrm{~h}$ of the feces sampling. Samples were collected from four animals per treatment at $15.8 \pm 1.8,38.4 \pm 1.5$, and $69.7 \pm 5.2$ days of life. The samples of feces were immediately oven dried at $55^{\circ} \mathrm{C}$ for $72 \mathrm{~h}$. Samples
Table 1 Ingredients and analyzed composition of dry matter (DM), crude protein $(\mathrm{CP})$ organic matter $(\mathrm{OM})$, ether extract $(\mathrm{EE})$, and neutral detergent fiber (NDF) of the diets components

\begin{tabular}{llll}
\hline Item & Starter & Coast-cross hay & Milk \\
\hline Dietary ingredient, g/kg & & & \\
$\quad$ Soybean meal & 325 & - & - \\
Corn meal & 626 & - & - \\
Wheat bran & 30.9 & - & - \\
Limestone & 11.2 & - & - \\
Dicalcium phosphate & 3.0 & - & - \\
Salt & 2.4 & - & - \\
Mineral mix ${ }^{\mathrm{a}}$ & 1.2 & - & - \\
Diet composition & & & 124 \\
DM, g/kg as fed & 862 & 871 & 239 \\
CP, g/kg of DM & 193 & 125 & 941 \\
OM, g/kg of DM & 973 & 889 & 257 \\
EE, g/kg of DM & 15.1 & 11.8 & - \\
NDF, g/kg of DM & 133 & 728 & \\
Apparent digestibility, g/kg & & & 940 \\
DM & 823 & 771 & 949 \\
CP & 773 & 785 & 934 \\
EE & 930 & 572 & 798 \\
CHO & 854 & & \\
\hline
\end{tabular}

${ }^{\mathrm{a}}$ Mineral mix: zinc sulfate— $500 \mathrm{~g} / \mathrm{kg}$; copper sulfate $-417 \mathrm{~g} / \mathrm{kg}$; cobalt sulfate $-28 \mathrm{~g} / \mathrm{kg}$; sodium selenite $-28 \mathrm{~g} / \mathrm{kg}$; and potassium iodate$28 \mathrm{~g} / \mathrm{kg}$

${ }^{\mathrm{b}} \mathrm{CHO}=$ total carbohydrates $(\mathrm{CHO}=\mathrm{OM}-\mathrm{EE}-\mathrm{CP})$

of milk, starter, and hay were collected daily during the digestibility trials. The apparent digestibility of each ingredient was calculated by regressing the ratio of dry matter (DM) intake of each feed and total DM intake as a function of total diet digestibility (Table 1). At the end of the trial, a composite sample with $10 \mathrm{~mL}$ of pure urine diluted in $40 \mathrm{~mL}$ sulfuric acid $0.036 \mathrm{~N}$ was made to quantify allantoin and uric acid. The absorbed purines (AP) were calculated from the urinary excretion of purine derivatives, according to Orellana Boero et al. (2001).

The ruminal synthesis of nitrogen compounds $(\mathrm{RN})$ was calculated as a function of the AP (Chen and Gomes 1992). The $\mathrm{RN}$ values were multiplied by the factor 6.25 for subsequent adjustments of regressions of the synthesis of microbial crude protein (MCP) as a function of animal age, body weight (BW), digestible energy intake, and intake of digestible energy from the starter. RN was not affected by any diet characteristic (starter and energy intake). However, RN was affected $(P<0.05)$ by the body weight $(\mathrm{BW})$, following the equation:

$$
\begin{aligned}
\mathrm{MCP}= & 12.89+0.708( \pm 0.158) \\
& \times \mathrm{BW},(\mathrm{RMSE}=15.93)
\end{aligned}
$$

where $\mathrm{MCP}=$ microbial crude protein $(\mathrm{g} /$ day $)$. 
To calculate the rumen-degradable protein (RDP), the synthesis of MCP was multiplied by 1.18 (NRC 2001) considering ammonia losses and $\mathrm{N}$ recycling. It was also considered that the composition of the RDP and rumen-undegradable protein (RUP) was proportional to the intake of protein from the milk and starter in the animal diet. Therefore, the truly digestible microbial crude protein (tdMCP) was calculated by the equation:

$\mathrm{tdMCP}=0.64 \times \mathrm{RDP}$,

where 0.64 is the factor, considering that $80 \%$ of the microbial protein is true and $80 \%$ is its intestinal digestibility (NRC 2001); RDP = rumen-degradable protein or microbial protein $(\mathrm{g} / \mathrm{kg}$ per EBWG).

The RUP was calculated as ingested crude protein $(\mathrm{CP})$ minus RDP, and the digestible RUP (dRUP) was calculated according to the following equation:

$$
\begin{aligned}
\mathrm{dRUP}= & (\mathrm{RUP} \times \mathrm{MDP} \times \mathrm{CPM}) \\
& +(\mathrm{RUP} \times \mathrm{SPD} \times \mathrm{CPS}),
\end{aligned}
$$

where MPD = milk protein digestibility; $\mathrm{CPM}=$ proportion of $\mathrm{CP}$ from the milk in the total diet; SPD = starter protein digestibility; $\mathrm{CPS}=$ proportion of $\mathrm{CP}$ from the starter in the total diet.

The metabolizable protein (MP) was calculated as the sum of tdMCP and dRUP. This procedure was performed at each 4-week interval (4 to $31 ; 32$ to $60 ; 61$ to 87 days), considering the respective proportions of $\mathrm{CP}$ from milk and the starter in the first two periods. In the period from 60 to 87 days, the total diet digestibility was considered for each treatment (Table 2).

The dietary values of EE, CP, and total carbohydrates (TC) were multiplied by their respective caloric equivalents (NRC 2001), and digestibility calculated for each nutrient in each treatment per interval of trial conducted, resulting in digestible energy intake. The metabolizable energy intake (MEI, g/day) was estimated by multiplying the digestible energy by the efficiency of use of digestible energy of diets with milk and the starter for calves of $93.4 \%$ (NRC 2001).

\section{Slaughter}

The slaughters were carried out by stunning the animals and causing a brain concussion, then subsequently sectioning the jugular vein until the animals bled out completely. After slaughter, each animal was separated into carcass (CAR), blood, hide, organs, head, hooves, and gastrointestinal tract (GIT). All parts were weighed individually, and the GIT was cleaned so that the sum of all parts would correspond to the empty body weight (EBW). The CAR was divided lengthwise into two halves, and then chilled at $4{ }^{\circ} \mathrm{C}$ for approximately $24 \mathrm{~h}$. After the chilling period, all right half-carcasses were ground in an industrial mill until homogenization, and then sampled. The non-carcass components (NCC: blood, leather, head, paws, organs, and the cleaned gastrointestinal tract) were weighed, ground, and sampled individually, and then a proportional composite sample was formed (approximately $25 \%$ of sum of total components), re-ground in an industrial mill until homogenization, and sampled. The composition of the EBW was calculated from the results of CAR and NCC, summed proportionally.

The initial EBW (iEBW) was estimated using data from the BS group, to convert body weight gain (BWG) into empty body weight gain (EBWG). The average value of EBWG to BWG ratios was used for each treatment. Using the data obtained from the BS animals, linear equations were generated to estimate the composition of the iEBW of each animal.

\section{Laboratory analysis}

All samples were lyophilized and ground (1 $\mathrm{mm}$ mesh sieve) and analyzed for dry matter (DM), organic matter (OM), and ash and crude protein (CP) according to Detmann et al. (2012). Ether extract (EE) was analyzed according to AOCS (2004). The neutral detergent fiber (NDF) contents of the hay and starter were estimated using F57 filter bags in a fiber analyzer (Ankom-220 Fiber Analyzer, ANKOM Technology, USA). The total carbohydrates from (TC) were calculated subtracting the EE and CP from the OM. To calculate the levels of body energy (RE) and retained energy, the caloric value of $39.19 \mathrm{MJ} /$ $\mathrm{kg}$ was assumed for the $\mathrm{EE}$ content and $23.79 \mathrm{MJ} / \mathrm{kg}$ for $\mathrm{CP}$.

\section{Energy requirements models}

Heat production (HP) from each animal was estimated as the difference between the MEI and RE. The net energy (NE) for maintenance $\left(\mathrm{NE}_{\mathrm{m}}\right)$ was obtained from the intercept of the exponential regression between HP and MEI (Lofgreen and Garrett 1968):

$\mathrm{HP}=\beta_{0} \times e^{\left(\beta_{1} \times \mathrm{MEI}\right)}$,

where $\mathrm{HP}=$ heat production $\left(\mathrm{MJ} / \mathrm{BW}^{0.75} / \mathrm{day}\right) ; \mathrm{MEI}=$ metabolizable energy intake $\left(\mathrm{MJ} / \mathrm{BW}^{0.75} /\right.$ day); $\beta_{0}$ and $\beta_{1}=$ regression parameters; $e=$ Euler number.

The metabolizable energy (ME) for maintenance $\left(\mathrm{ME}_{\mathrm{m}}\right.$, $\mathrm{MJ} / \mathrm{BW}^{0.75} /$ day) was estimated by the iterative method, when MEI equals HP in the Eq. [4] (Lofgreen and Garrett 1968). The efficiency of use of ME for maintenance $\left(k_{\mathrm{m}}\right)$ was obtained from the ratio between the $\mathrm{NE}_{\mathrm{m}}$ and $\mathrm{ME}_{\mathrm{m}}$.

The energy content (EC; MJ) in the body of all animals (including BS group) was regressed as a function of the EBW, according to the allometric model (ARC 1980):

$\mathrm{EC}=a \times \mathrm{EBW}^{b}$,

where $\mathrm{EC}=$ energy content $(\mathrm{MJ})$; EBW = empty body weight $(\mathrm{kg}) ; a$ and $b=$ regression parameters. 
Table 2 Apparent digestibility $(\mathrm{g} / \mathrm{kg})$ of dry matter (DM), crude protein $(\mathrm{CP})$, ether extract (EE), and total carbohydrates $(\mathrm{CHO})$ of Holstein calves diets

\begin{tabular}{|c|c|c|c|c|c|c|c|c|c|c|c|}
\hline \multirow[t]{2}{*}{ Component } & \multicolumn{4}{|c|}{ Milk (kg/day) } & \multicolumn{3}{|c|}{ Period } & \multirow[t]{2}{*}{ SEM } & \multicolumn{3}{|c|}{$P$ value } \\
\hline & 2 & 4 & 6 & 8 & 1 & 2 & 3 & & $M^{\mathrm{a}}$ & $P^{\mathrm{b}}$ & $M \times P$ \\
\hline $\mathrm{DM}, \mathrm{g} / \mathrm{kg}$ & 870 & 907 & 905 & 936 & 908 & 914 & 891 & 0.7 & 0.067 & 0.133 & 0.091 \\
\hline $\mathrm{CP}, \mathrm{g} / \mathrm{kg}$ & 860 & 889 & 922 & 934 & 907 & 912 & 885 & 1.0 & 0.062 & 0.141 & 0.099 \\
\hline $\mathrm{EE}, \mathrm{g} / \mathrm{kg}$ & 804 & 897 & 878 & 898 & 887 & 939 & 781 & 1.5 & 0.007 & $<0.001$ & 0.007 \\
\hline $\mathrm{CHO}^{\mathrm{c}}, \mathrm{g} / \mathrm{kg}$ & 929 & 961 & 934 & 957 & 982 & 961 & 893 & 0.8 & 0.493 & $<0.001$ & 0.066 \\
\hline
\end{tabular}

${ }^{\mathrm{a}} M=$ effect of milk level

${ }^{\mathrm{b}} P=$ effect of period or trial

${ }^{\mathrm{c}} \mathrm{CHO}=\mathrm{OM}-\mathrm{EE}-\mathrm{CP}$
The net energy for gain $\left(\mathrm{NE}_{\mathrm{g}}, \mathrm{MJ} / \mathrm{kg}\right.$ EBWG) was estimated from the derivative of Eq. [5], according to the model (ARC 1980):

$\mathrm{NE}_{\mathrm{g}}=a \times b \times \mathrm{EBW}^{(b-1)}$,

where $\mathrm{EBW}=$ empty body weight $(\mathrm{kg}) ; a$ and $b=$ parameters of the model. The derivative of this model is interpreted as the $\mathrm{RE}(\mathrm{MJ})$ for $1 \mathrm{~kg}$ of EBWG.

The regression of RE $\left(\mathrm{MJ} / \mathrm{EBW}^{0.75} /\right.$ day $)$ as a function of MEI $\left(\mathrm{MJ} / \mathrm{EBW}^{0.75} /\right.$ day $)$ was tested for linearity $(P<0.0001)$; thus, the efficiency of use of ME for gain $\left(k_{\mathrm{g}}\right)$ was obtained from the regression slope.

\section{Protein requirements models}

The net protein requirements $(\mathrm{NP})$ for maintenance $\left(\mathrm{NP}_{\mathrm{m}}\right)$ was estimated according to the model:

$\mathrm{RP}=\beta_{0}+\beta_{1} \times \mathrm{MPI}$,

where $\mathrm{RP}=$ retained protein $\left(\mathrm{g} / \mathrm{BW}^{0.75} / \mathrm{day}\right) ; \mathrm{MPI}=\mathrm{MP}$ intake $\left(\mathrm{g} / \mathrm{kg} \mathrm{BW} \mathrm{BW}^{0.75} /\right.$ day $) ; \beta_{0}=$ net protein for maintenance $\left(\mathrm{NP}_{\mathrm{m}} \mathrm{g} / \mathrm{BW}^{0.75}\right)$; and $\beta_{1}=$ efficiency of use of metabolizable protein for gain $\left(k_{\mathrm{pg}}\right)$. The intercept of this regression was assumed equal to the endogenous and metabolic losses of protein, which is assumed as $\mathrm{NP}_{\mathrm{m}}$.

The $\mathrm{MP}_{\mathrm{m}}$ was estimated regressing MPI (g/day) as a function of the EBWG (g/day), and the obtained intercept was divided by the mean of $\mathrm{BW}^{0.75}$ of the calves (Wilkerson et al. 1993). The efficiency of use of MP for maintenance $\left(k_{\mathrm{pm}}\right)$ was calculated by the ratio $\mathrm{NP}_{\mathrm{m}}: \mathrm{MP}_{\mathrm{m}}$.

The net protein requirements for gain $\left(\mathrm{NP}_{\mathrm{g}} ; \mathrm{g} / \mathrm{kg}\right.$ EBWG) were estimated by the allometric model of the body protein content (PC) as a function of the EBW, as described for $\mathrm{NE}_{\mathrm{g}}$ (ARC 1980). The MP for gain $\left(\mathrm{MP}_{\mathrm{g}}\right.$ ) was calculated by dividing $\mathrm{NP}_{\mathrm{g}}$ by the $k_{\mathrm{pg}}$ value found in Eq. [7].

\section{Statistical analysis}

Calves were assigned to a completely randomized design of four milk feeding levels $(2,4,6$, and $8 \mathrm{~kg} /$ day of raw milk) arranged in a $4 \times 2$ factorial by slaughter age (59 and 87 days old). The data pertaining to intake, performance, and body composition were analyzed considering the effects of milk and slaughter age and their interaction, evaluating the linear, quadratic, and cubic contrasts for milk levels. Digestibility data were analyzed considering period as repeated measures with calves as subject. The linear models were tested using the PROC MIXED procedure, whereas the non-linear models were tested with PROC NLIN (SAS Inst. Inc., Cary, NC). Kenward-Roger approximation was used to calculate the residual degrees of freedom. Removed outliers were selected when they do not follow the biological data pattern and were removed only if the Internal Studentized residual was outside the \pm 2 range values. The significance of the parameters was declared at $P<0.05$. For the factorial model, the significance of the effects was declared at $P<0.05$ and tendencies at $P<0.10$.

\section{Results}

\section{Performance and body composition}

Slaughter age affected EBW:SBW and EBWG:BWG ratios (Table 3). The EBW:SBW values of 0.95 and 0.85 and EBWG:BWG of 0.93 and 0.77 were observed for animals slaughtered at 59 and 87 days, respectively (Table 3). Higher levels of milk had greater BWG, EBWG, and RE, explained by the greater DMI, MPI, and MEI, all increasing linearly $(P<0.05)$. Fat and protein contents in EBW increased linearly (Table 3) to the increase in milk volume $(P<0.05)$, while water decreased $(P<0.05)$. 
Table 3 Effects of milk level and slaughter age on performance, intake, energy balance, and body composition of Holstein young calves in tropical condition

\begin{tabular}{|c|c|c|c|c|c|c|c|c|c|c|c|c|c|}
\hline \multirow[t]{2}{*}{ Item $^{\mathrm{a}}$} & \multirow[t]{2}{*}{ BS } & \multicolumn{4}{|c|}{ Milk (kg/day) } & \multicolumn{2}{|l|}{ SA } & \multirow[t]{2}{*}{ SE } & \multicolumn{3}{|l|}{ Milk } & \multirow[t]{2}{*}{ SA } & \multirow[t]{2}{*}{ Milk $\times$ SA } \\
\hline & & 2 & 4 & 6 & 8 & 59 & 87 & & Linear & Quad. & Cubic & & \\
\hline No. of calves & 10 & 7 & 7 & 7 & 8 & 13 & 16 & - & - & - & - & - & - \\
\hline Initial BW, kg & - & 32.2 & 37.3 & 32.6 & 38.7 & 34.2 & 36.2 & 1.08 & 0.103 & 0.804 & 0.074 & 0.309 & 0.292 \\
\hline SBW, kg & 34.9 & 46.3 & 66.7 & 70.9 & 85.1 & 50.6 & 83.9 & 4.44 & $<0.001$ & 0.503 & 0.220 & $<0.001$ & 0.575 \\
\hline EBW, kg & 33.9 & 40.8 & 60.2 & 63.2 & 76.4 & 48.5 & 71.8 & 3.66 & $<0.001$ & 0.468 & 0.172 & $<0.001$ & 0.468 \\
\hline EBW/SBW & 0.97 & 0.88 & 0.90 & 0.89 & 0.90 & 0.95 & 0.85 & 0.01 & 0.756 & 0.914 & 0.999 & $<0.001$ & 0.365 \\
\hline \multicolumn{14}{|l|}{ Performance ${ }^{b}$} \\
\hline BWG, g/day & - & 160 & 375 & 526 & 723 & 326 & 547 & 0.05 & $<0.001$ & 0.883 & 0.677 & 0.003 & 0.295 \\
\hline EBWG, g/day & - & 131 & 311 & 440 & 623 & 314 & 427 & 0.05 & $<0.001$ & 0.854 & 0.613 & 0.058 & 0.299 \\
\hline EBWG/BWG & - & 0.82 & 0.83 & 0.84 & 0.86 & 0.93 & 0.77 & 0.02 & 0.322 & 0.892 & 0.836 & $<0.001$ & 0.205 \\
\hline \multicolumn{14}{|l|}{ Intake and energy balance ${ }^{c}$} \\
\hline Milk $^{\mathrm{d}}$, g DM/day & & 269 & 511 & 692 & 898 & 603 & - & 32.2 & $<0.001$ & 0.562 & 0.554 & - & - \\
\hline Starter, g DM/day & & 399 & 518 & 441 & 483 & 111 & 810 & 46.1 & 0.394 & 0.400 & 0.134 & $<0.001$ & 0.472 \\
\hline $\mathrm{Hay}^{\mathrm{e}}, \mathrm{g} \mathrm{DM} /$ day & & 104 & 126 & 142 & 109 & - & 119 & 31.2 & 0.812 & 0.353 & 0.734 & - & - \\
\hline MPI, g/day & - & 89 & 145 & 163 & 207 & 133 & 169 & 10.0 & $<0.001$ & 0.487 & 0.116 & $<0.001$ & 0.291 \\
\hline MEI, MJ/day & - & 9.8 & 16.2 & 17.7 & 22.3 & 14.7 & 18.3 & 0.96 & $<0.001$ & 0.329 & 0.064 & $<0.001$ & 0.585 \\
\hline $\mathrm{RE}, \mathrm{MJ} /$ day & - & 0.29 & 1.59 & 2.68 & 3.73 & 1.93 & 2.22 & 0.54 & $<0.001$ & 0.839 & 0.924 & 0.596 & 0.475 \\
\hline $\mathrm{HP}, \mathrm{MJ} / \mathrm{BW}^{0.75}$ day $^{-1}$ & - & 0.61 & 0.76 & 0.80 & 0.84 & 0.76 & 0.75 & 0.04 & $<0.001$ & 0.232 & 0.501 & 0.640 & 0.571 \\
\hline \multicolumn{14}{|l|}{ Body composition $^{\mathrm{f}}$} \\
\hline EE, g/kg EBW & 45.7 & 35.0 & 50.9 & 55.6 & 61.1 & 52.7 & 48.6 & 2.54 & 0.002 & 0.332 & 0.616 & 0.443 & 0.303 \\
\hline $\mathrm{CP}, \mathrm{g} / \mathrm{kg}$ EBW & 179 & 159 & 158 & 164 & 167 & 168 & 158 & 2.18 & 0.041 & 0.451 & 0.702 & 0.030 & 0.322 \\
\hline Ash, g/kg EBW & 46.8 & 42.7 & 41.9 & 39.7 & 41.2 & 42.4 & 40.3 & 0.99 & 0.401 & 0.549 & 0.537 & 0.239 & 0.328 \\
\hline $\mathrm{H}_{2} \mathrm{O}, \mathrm{g} / \mathrm{kg}$ EBW & 728 & 763 & 749 & 740 & 728 & 737 & 753 & 7.94 & 0.005 & 0.904 & 0.796 & 0.078 & 0.871 \\
\hline
\end{tabular}

$S A$ slaughter age, $S E$ standard error

${ }^{\text {a } I t e m: ~ B W ~=~ b o d y ~ w e i g h t ; ~ S B W ~=~ s l a u g h t e r ~ b o d y ~ w e i g h t ; ~ E B W ~=~ e m p t y ~ b o d y ~ w e i g h t ~}$

${ }^{\mathrm{b}}$ Performance: $\mathrm{BWG}=$ body weight gain; EBWG = empty body weight gain

${ }^{\mathrm{c}}$ Intake and energy balance: DMI = dry matter intake; MPI = metabolizable protein intake; $\mathrm{MEI}=$ metabolizable energy intake; RE = retained energy;

${ }^{12} \mathrm{HP}=$ heat production

${ }^{\mathrm{d}}$ Milk: Analyzed with data of both slaughter age, considering the milk intake of 87 days old group before weaning

${ }^{\mathrm{e}}$ Hay: Analyzed with data between weaning and slaughter of the animals slaughtered at 87 days old

${ }^{\mathrm{f}}$ Body composition: $\mathrm{EE}=$ ether extract; $\mathrm{CP}=$ crude protein

\section{Energy requirements}

Data and estimates of energy requirements are shown in Fig. 1. The equation used to describe $\mathrm{HP}\left(\mathrm{MJ} / \mathrm{BW}^{0.75}\right)$ as a function of $\mathrm{MEI}\left(\mathrm{MJ} / \mathrm{BW}^{0.75}\right)$ was:

$$
\begin{aligned}
\mathrm{HP}= & 0.364( \pm 0.034) \\
& \times e^{0.836( \pm 0.103) \times \mathrm{MEI}},(\mathrm{RMSE}=0.003)
\end{aligned}
$$

The intercept of the regression represents value of $0.36 \mathrm{MJ} / \mathrm{BW}^{0.75} \mathrm{day}^{-1}$ found for $\mathrm{NE}_{\mathrm{m}}$. The observed $\mathrm{ME}_{\mathrm{m}}$ calculated interactively was $0.61 \mathrm{MJ} / \mathrm{BW}^{0.75}$ day $^{-1}$ MJ. The $k_{\mathrm{m}}$ value found from the ratio between $\mathrm{NE}_{\mathrm{m}}$ and $\mathrm{ME}_{\mathrm{m}}$ was $59.4 \%$.
The estimated equation for $\mathrm{NE}_{\mathrm{g}}(\mathrm{MJ} / \mathrm{kg}$ EBWG) was:

$4.402 \times \mathrm{EBW}^{0.099},(\mathrm{RMSE}=0.011)$

The $k_{\mathrm{g}}$ was $46.5 \%(\mathrm{RMSE}=0.014)($ Fig. 1$)$.

\section{Protein requirements}

The $\mathrm{NP}_{\mathrm{m}}$ and $\mathrm{MP}_{\mathrm{m}}$ were 3.67 and $3.88 \mathrm{~g} / \mathrm{kg} \mathrm{BW}{ }^{0.75}$, respectively (Fig. 2). Diving $\mathrm{NP}_{\mathrm{m}}$ by $\mathrm{MP}_{\mathrm{m}}$, a $k_{\mathrm{pm}}$ of $94.6 \%$ was estimated. The equation for $\mathrm{NP}_{\mathrm{g}}(\mathrm{g} / \mathrm{kg}$ EBWG) was:

$\mathrm{NP}_{\mathrm{g}}=188.8 \times \mathrm{EBW}^{-0.042},(\mathrm{RMSE}=13.56)$ 

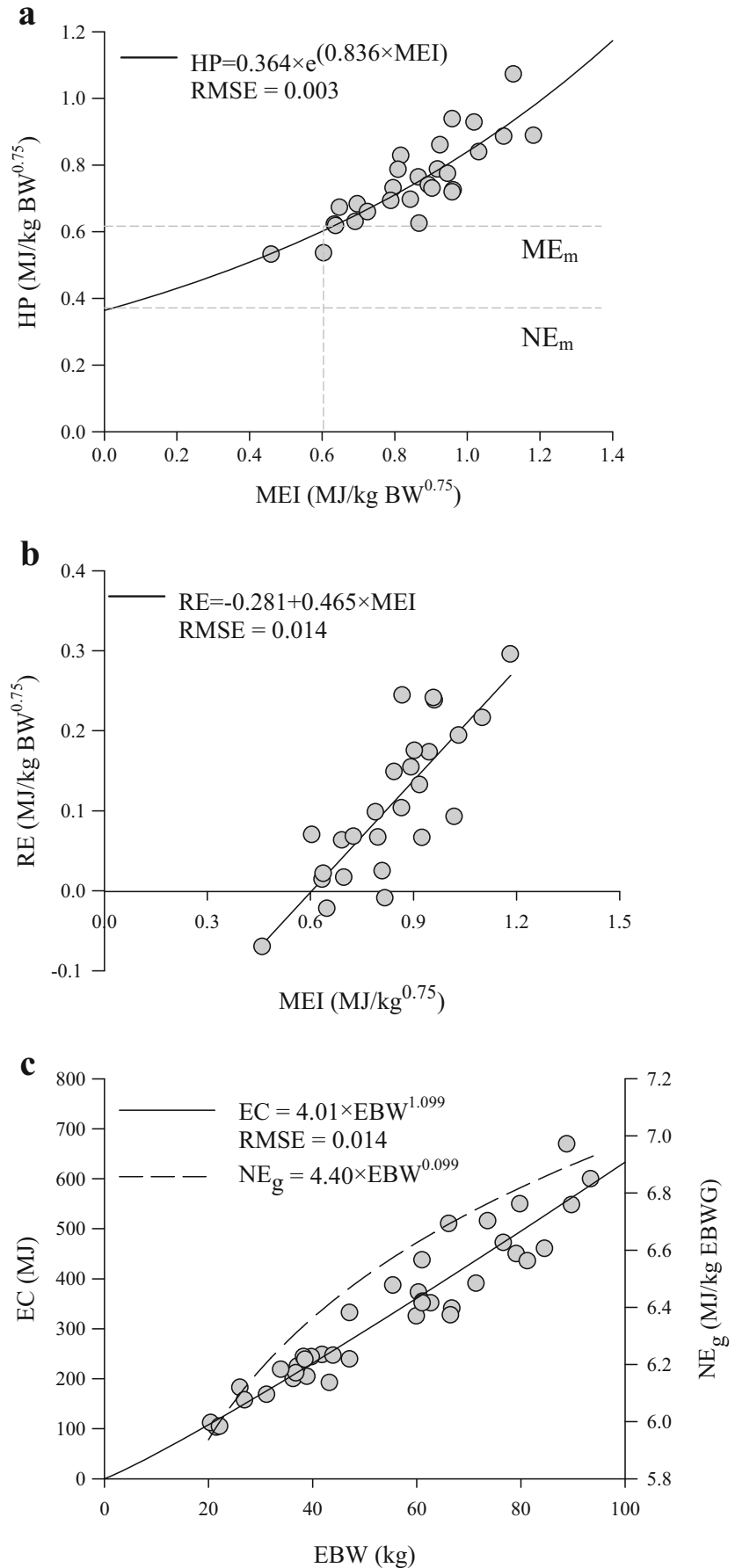

Fig. 1 Data and estimates of energy requirements for maintenance $\left(\mathrm{NE}_{\mathrm{m}}\right.$ and $\left.\mathrm{ME}_{\mathrm{m}} ; \mathbf{a}\right)$, efficiency of utilization of energy for gain $\left(k_{\mathrm{g}} ; \mathbf{b}\right)$, and net energy requirements for growth $\left(\mathrm{NE}_{\mathrm{g}} ; \mathbf{c}\right)$ of Holstein young calves in tropical condition. $(H P=$ heat production; $M E I=$ metabolizable energy intake; $R E=$ retained energy; $E B W=$ empty body weight; $E B W G=$ empty body weight gain; $E C=$ energy content in empty body weight)

Regressing the RP ( $\mathrm{g} / \mathrm{kg} \mathrm{EBW}^{0.75} /$ day) as a function of MPI (g/kg EBW ${ }^{0.75} /$ day) (Fig. 2), the following equation was obtained:

$\mathrm{RP}=3.67( \pm 1.27)+0.826( \pm 0.167) \times \mathrm{MPI},(\mathrm{RMSE}=1.455)$

The $k_{\text {pg }}$ was $82.6 \%$ (Fig. 2).
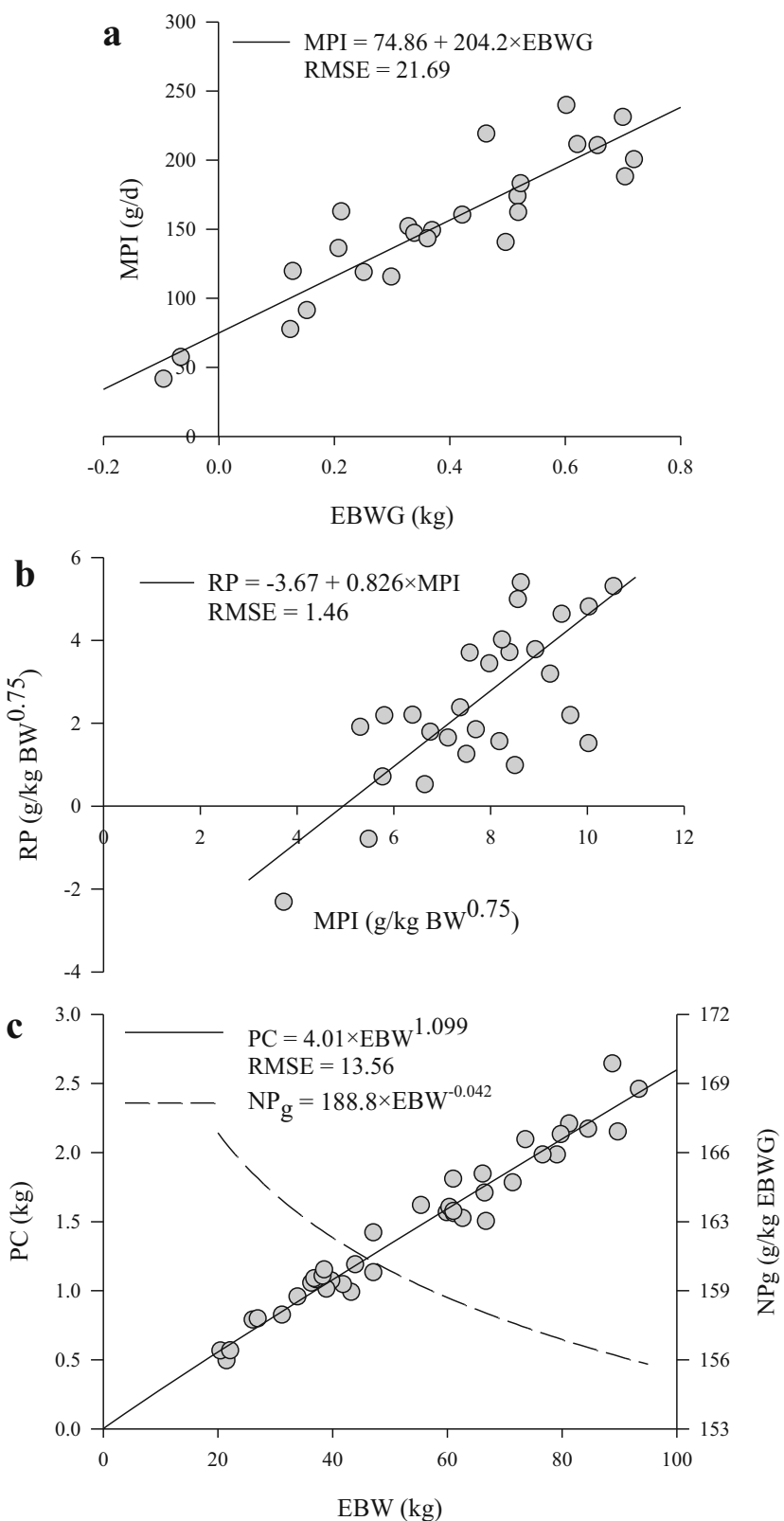

Fig. 2 Data and estimates of protein requirements for maintenance (a), efficiency of utilization of protein for gain (b), and net requirements of protein for growth $\left(\mathrm{NP}_{\mathrm{g}} ; \mathbf{c}\right)$ of Holstein young calves in tropical condition

\section{Discussion}

Feeding the calves with hay after weaning increased the volume of rumen and gastrointestinal tract, which explains the reduction in EBW:SBW in EBWG:BWG ratios (Table 3). The EBW:SBW values of 0.96 and 0.86 for calves at 59 and 87 days old are nutritionally coherent and can be recommended. The NRC (2001) adopts an EBW per BW ratio of 0.89 , obtained with heifers weighing over $100 \mathrm{~kg}$. However, we believe that our observed values are more accurate and specific for young calves. Our results take into 
account dietary changes, given that alterations in these ratios are significant in this animal development phase. The linear increase (Table 3 ) in body fat and proteins in response to milk level is consistent with the study by Bartlett et al. (2006), which observed greater fat deposition when MEI increased.

The obtained $\mathrm{NE}_{\mathrm{m}}\left(0.36 \mathrm{MJ} / \mathrm{BW}^{0.75}\right.$; Eq. 8$)$ was equal to the $\mathrm{NE}_{\mathrm{m}}$ recommended by NRC (2001). The NRC (2001) uses data most based on calorimetric techniques and considers different $k_{\mathrm{m}}$ values of 86 and $75 \%$, for milk and starter, respectively, resulting in $\mathrm{ME}_{\mathrm{m}}$ around $0.42 \mathrm{MJ} / \mathrm{kg} \mathrm{BW}^{0.75}$, which was lower than the result of $0.61 \mathrm{MJ} / \mathrm{BW}^{0.75}$ found in this study. The $k_{\mathrm{m}}$ can be overestimated by calorimetric methods and underestimated when adopting comparative slaughter (Johnson 1986). Besides methodological factors, the tropical conditions of the experiment may reduce the $k_{\mathrm{m}}$ due to losses in homeostasis mechanisms (Close and Mount 1978), such as increased respiratory frequency. The high feeding levels, inherent to the comparative slaughter technique, and the greater intake of hay and starter might have been imposing factors over the higher requirements of $\mathrm{ME}_{\mathrm{m}}$ (Johnson 1986; Labussiere et al. 2008). Gerrits et al. (1996) observed $\mathrm{ME}_{\mathrm{m}}$ of 0.39 and $0.45 \mathrm{MJ} / \mathrm{BW}^{0.75}$. Schrama et al. (1992) observed a $\mathrm{ME}_{\mathrm{m}}$ of $0.56 \mathrm{MJ} / \mathrm{BW}^{0.75}$ for calves from 6 to 14 days old. The $\mathrm{ME}_{\mathrm{m}}$ values observed in the present study may differ from those observed by Gerrits et al. (1996) due to the decrease in the $\mathrm{ME}_{\mathrm{m}}$ as the weight increases. This variation can be highly significant in this phase because of the constant rumen development and higher costs for the immune systems of young animals. These factors are more significant in younger animals, such as those used in our work, explaining the proximity of our estimated $\mathrm{ME}_{\mathrm{m}}$ with the requirements observed by Schrama et al. (1992).

The observed $k_{\mathrm{g}}$ of $47.1 \%$ is lower than $65.2 \%$ suggested by NRC (2001). The estimates of $\mathrm{NE}_{\mathrm{g}}$ and $k_{\mathrm{g}}$ have limitations inherent to the techniques utilized (Tedeschi et al. 2010), and the values adopted by the NRC (2001) are based on the dietary concentration of ME as well as methods with respirometric chambers, which overestimate $k_{\mathrm{g}}$ (Johnson 1986). Other studies with comparative slaughter have also shown $k_{\mathrm{g}}$ values lower than those adopted by NRC (2001) (Gerrits et al. 1996; Tikofsky et al. 2001; Bartlett et al. 2006). The fraction of energy deposited as protein per unit of gain is greater in younger animals, and thus the lower value of $k_{\mathrm{g}}$ may be related to the higher energy cost of protein deposition (Rattray et al. 1974). The $\mathrm{ME}_{\mathrm{m}}$ and $\mathrm{ME}_{\mathrm{g}}$ proposed by NRC (2001) may be underestimated for young calves in tropical conditions due to higher and variable basal metabolism of young animals, and also due to the possibility of a lower metabolism of the nutrients in the diet, because of the immaturity of the digestive tract (Arieli et al. 1995).

The observed result for $\mathrm{MP}_{\mathrm{m}}$ is greater than $3.52 \mathrm{~g} / \mathrm{kg}$ $\mathrm{BW}^{0.75}$ reported by Smuts (1935) for adult animals. The greater growth rates in young animals resulted in greater protein turnover (Liu et al. 1995), which is higher in younger animals, explaining the greater maintenance requirements in calves. Our results have limitations such as the use of the 1.18 factor to estimate RDP from MCP (NRC 2001). Berends et al. (2014) verified that rumen degraded milk nitrogen can be recycled into the rumen, be used in the small intestine for anabolism, and is affected by starter intake level. Moreover, measures of ammonia $\mathrm{N}$ loss in calves are scarce in the literature, and the value of 1.18 (NRC 2001) must be used carefully with young animals.

The observed RP ranging from 156 to $169 \mathrm{~g} / \mathrm{kg}$ EBWG (Fig. 2) is lower than the value of $30 \mathrm{~g} / \mathrm{kg} \mathrm{BWG}$ recommended by the NRC (2001). The exponent associated with EBW (Eq. 10) being close to zero can be interpreted as a low variation in the retention of protein as live weight is increased, which can be explained by the fact that the animals were far from maturity.

According to Tamminga and Oldham (1980), the efficiency of use of MP is based on the protein biological value, and it is strongly affected by the quality of the protein source, which may explain the higher $k_{\mathrm{pm}}$ value of $94.6 \%$, close to the $100 \%$ recommended by the AFRC (1993) for high biological value diets. The high $k_{\mathrm{pg}}$ observed can be explained by the high biological value of the dietary protein, which largely comes from the milk. Furthermore, animals with a lower age deposit protein more efficiently (Ainslie et al. 1993).

Our results generated greater protein requirements than those reported by the NRC (2001), who used digestible protein values by the factorial method (Blaxter and Mitchell 1948). The use of the factorial method to estimate nutritional requirements of protein for calves has a limitation related to demand for accurate estimates of DMI to predict endogenous $\mathrm{N}$ losses. Moreover, the factorial method can underestimate the N losses (Quiniou et al. 1995; MacRae et al. 2010). Bascom et al. (2007) evaluated protein levels for young calves and observed performance that was lower than expected; they attributed this outcome to the possibility of underestimation of protein for maintenance by the NRC (2001). Thus, the use of data based on comparative slaughter and with different approaches to the factorial method can be feasible alternatives to avoid these variations when estimating protein requirements for young calves.

Our results indicate that young Holstein calves in tropical conditions have a lower efficiency of use of energy and have protein requirements for maintenance greater than the estimates made by the NRC (2001). The proposed energy and protein estimates present nutritional coherence and should be evaluated in the prediction of nutrient requirements of young Holstein calves under different management scenarios. The demand for consistent starter intake models in tropical conditions with different feed programs becomes more evident, since, in conjunction with our data, it can allow a best fit of calves' requirements. Additional studies are needed for the better prediction of protein utilization by calves. 
Acknowledgments The authors acknowledge financial support from Fundação de Amparo à Pesquisa do estado de Minas Gerais (FAPEMIG; APQ-01403-11) and Instituto Nacional de Ciência e Tecnologia-Ciência Animal (INCT-CA).

\section{Compliance with ethical standards}

Conflict of interest The authors declare that they have no conflict of interest.

\section{References}

AFRC. 1993. Energy and Protein Requirements of Ruminants. An Advisory Manual Prepared by the AFRC Technical Committee on Responses to Nutrients. CAB International, London.

Ainslie, S. J., D. G. Fox, T. C. Perry, D. J. Ketchen, and M. C. Barry. 1993. Predicting amino acid adequacy of diets fed to Holstein steers. J. Anim. Sci. 71:1312-9.

AOCS, 2004. Official Method Am 5-04 Oil. Rapid Determination of Oil/ Fat Utilizing High Temperature Solvent Extraction. Additions and Revisions to the Official Methods and Recommended Practices of the AOCS

ARC. 1980. The Nutrient Requirements of Ruminant Livestock. Agric. Res. Council, Commonwealth Agric. Bureaux, Slough, U.K.

Arieli, A., J. W. W. Schrama, W. Van der Hel, and M. W. A. W. Verstegen. 1995. Development of metabolic partitioning of energy in young calves. J. Dairy Sci. 78:1154-62.

Bartlett, K. S., F. K. McKeith, M. J. VandeHaar, G. E. Dahl, and J. K. Drackley. 2006. Growth and body composition of dairy calves fed milk replacers containing different amounts of protein at two feeding rates. J. Anim. Sci. 84:1454-67.

Bascom, S. a, R. E. James, M. L. McGilliard, and M. Van Amburgh. 2007. Influence of dietary fat and protein on body composition of Jersey bull calves. J. Dairy Sci. 90:5600-9.

Berends, H., J. J. G. C. van den Borne, B. A. Røjen, J. van Baal, and W. J. J. Gerrits. 2014. Urea recycling contributes to nitrogen retention in calves fed milk replacer and low-protein solid feed. J. Nutr. 144: 1043-9.

Blaxter, K. L., and H. H. Mitchell. 1948. The Factorization of the Protein Requirements of Ruminants and of the Protein Values of Feeds, with Particular Reference to the Significance of the Metabolic Fecal Nitrogen. J. Anim. Sci. 7:351-372.

Chen, X. B., and M. J. Gomes. 1992. Estimation of microbial protein supply to sheep and cattle based on urinary excretion of purine derivatives-An overview of the technical details. Occasional Publication. Rowett Research Institute, Bucksburn, Aberdeen, UK.

Close, W. H., and L. E. Mount. 1978. The effects of plane of nutrition and environmental temperature on the energy metabolism of the growing pig. Br. J. Nutr. 40:413.

Detmann, E., M. A. de Souza, S. de C. Valadares Filho, A. C. de Queiroz, T. T. Berchielli, E. de O. S. Saliba, L. da S. Cabral, D. dos S. Pina, M. M. Ladeira, and J. A. G. Azevedo. 2012. Métodos para análise de alimentos. 1st ed. Suprema, Visconde do Rio Branco, MG.
Gerrits, W. J. J., G. H. Tolman, J. W. Schrama, S. Tamminga, M. W. Bosch, and M. W. Verstegen. 1996. Effect of protein and proteinfree energy intake on protein and fat deposition rates in preruminant calves of 80 to $240 \mathrm{~kg}$ live weight. J. Anim. Sci. 74:2129-2139.

Johnson, D. E. 1986. Fundamentals of whole animal calorimetry: use in monitoring body tissue deposition. J. Anim. Sci. 63:111-114.

Labussiere, E., S. Dubois, J. van Milgen, G. Bertrand, and J. Noblet. 2008. Effects of dietary crude protein on protein and fat deposition in milk-fed veal calves. J. Dairy Sci. 91:4741-54.

Liu, Q., M. C. Lanari, and D. M. Schaefer. 1995. A review of dietary vitamin E supplementation for improvement of beef quality. J. Anim. Sci. 73:3131-40.

Lofgreen, G. P., and W. N. Garrett. 1968. A System for Expressing Net Energy Requirements and Feed Values for Growing and Finishing Beef Cattle. J Anim Sci 27:793-806.

MacRae, J. C., A. Walker, D. Brown, and G. E. Lobley. 2010. Accretion of total protein and individual amino acids by organs and tissues of growing lambs and the ability of nitrogen balance techniques to quantitate protein retention. Anim. Prod. 57:237-245.

NRC. 2001. Nutrient Requirements of Dairy Cattle. 7th ed. National Academy Press, Washington, DC., USA.

Orellana Boero, P., J. Balcells, S. . Martín-Orúe, J. . Liang, and J. . Guada. 2001. Excretion of purine derivatives in cows: endogenous contribution and recovery of exogenous purine bases. Livest. Prod. Sci. $68: 243-250$

Quiniou, N., S. Dubois, and J. Noblet. 1995. Effect of dietary crude protein level on protein and energy balances in growing pigs: comparison of two measurement methods. Livest. Prod. Sci. 41:51-61.

Rattray, P. V, W. N. Garrett, N. Hinman, and N. E. East. 1974. Energy Cost of Protein and Fat Deposition in Sheep. J. Anim. Sci. 38:378382.

Schrama, J. W., W. van der Hel, A. Arieli, and M. W. Verstegen. 1992. Alteration of energy metabolism of calves fed below maintenance during 6 to 14 days of age. J. Anim. Sci. 70:2527-32.

Silva, A. L., M. I. Marcondes, J. P. P. Rodrigues, and M. L. Chizzotti. 2014. New findings on dry matter intake prediction in dairy calves.D. M. McNeill and A. W. Bell, editors. Model. Nutr. Dig. Util. Farm Anim. 54:60. Available from: http://www.publish.csiro. $\mathrm{au} /$ ?act=view file\& file id=ANv54n12abstracts.pdf

Smuts, D. B. 1935. The Relation Between the Basal Metabolism and the Endogenous Nitrogen Metabolism, with Particular Reference to the Estimation of the Maintenance Requirement of Protein. J. Nutr. 9: 403-433.

Tamminga, S., and J. D. Oldham. 1980. Amino acid utilisation by dairy cows. II. Concept of amino acid requirements. Livest. Prod. Sci. 7: 453-463.

Tedeschi, L. O., D. G. Fox, G. E. Carstens, C. L. Ferrell, and G. M. Crovetto. 2010. The partial efficiency of use of metabolisable energy for growth in ruminants. In: Energy and protein metabolism and nutrition. 3rd EAAP International Symposium on Energy and Protein Metabolism and Nutrition, Parma, Italy, 6-10 September, 2010. Wageningen Academic Publishers. p. 519-529.

Tikofsky, J. N., M. E. Van Amburgh, and D. A. Ross. 2001. Effect of varying carbohydrate and fat content of milk replacer on body composition of Holstein bull calves. J. Anim. Sci. 79:2260-2267.

Wilkerson, V. a, T. J. Klopfenstein, R. a Britton, R. a Stock, and P. S. Miller. 1993. Metabolizable protein and amino acid requirements of growing cattle. J. Anim. Sci. 71:2777-84. 